HOW STRONG IS THE CASE

FOR DOLLARIZATION IN CENTRAL AMERICA?

AN EMPIRICAL ANALYSIS OF

BUSINESS CYCLES, CREDIT MARKET

IMPERFECTIONS AND THE EXCHANGE RATE

Nannette Lindenberg and Frank Westermann

Working Paper 83

August 2010

INSTITUTE OF EMPIRICAL ECONOMIC RESEARCH

University of Osnabrück

Rolandstrasse 8

49069 Osnabrück

Germany 


\title{
How Strong is the Case for Dollarization in Central America? \\ An Empirical Analysis of Business Cycles, Credit Market Imperfections \\ and the Exchange Rate
}

\author{
Nannette Lindenberg* \\ University of Osnabrück \\ Frank Westermann \\ University of Osnabrück \\ \& CESifo
}

August 5, 2010

\begin{abstract}
In this paper, we contrast two different views in the debate on official dollarization. The Mundell (1961) framework of optimal currency areas and a model on boom-bust cycles, by Schneider and Tornell (2004), who take account of credit market imperfections prevalent in middle income countries. We highlight that the role of the exchange rate is strikingly different in the two models. While in the Mundell framework the exchange rate is expected to smooth the business cycle, the other model predicts that the exchange rate plays an amplifying role. We empirically evaluate both models for eight highly dollarized Central American economies, and find that the main benefit of official dollarization derives from avoiding a mismatch between foreign currency liabilities and domestic revenues, as well as the boom-bust episodes that are likely to follow from it. Using a new method of Cubadda (1999, 2007), we furthermore test for cyclical comovement and reject the hypothesis that the countries form an optimal currency area with the United States according to the Mundell definition.
\end{abstract}

Keywords: dollarization, real exchange rate, business cycle comovement, serial correlation common feature, boom-bust cycles, credit market imperfections, Central America

JEL: E32, E52, F36, O54

${ }^{*}$ Both authors are at the University of Osnabrück, Institute of Empirical Economic Research, Rolandstr. 8, D-49069 Osnabrück. E-mail: nannette.lindenberg@uos.de and frank.westermann@uos.de 


\section{Introduction}

Unofficial dollarization has increased substantially over the past decade in Central America and in several countries the $50 \%$ mark has been crossed in recent years. There is a high degree of de facto dollarization $^{1}$ and the issue of official dollarization has therefore become an important part of the discussion on stabilization policy. Recently, for instance, one of the presidential candidates of the Costa Rican elections of February 2010, Otto Guevara, proposed to dollarize the economy officially, a proposal that is also supported by the ex president of the central bank, Eduardo Lizano, and further politicians and academics. The issue of official dollarization is also an important part of the policy debate in many of the other Central American countries, of which Panama and El Salvador already have the US Dollar as an official currency since 1904 and $2001 .^{2}$

Despite the increasing political discussion, there is so far only little empirical evidence on the economic cost and benefit of a dollarization policy in Central American countries. ${ }^{3}$ Partly, this may be due to the lack of an easy to use comprehensive empirical framework to address the issue of dollarization and its implications for stabilization policy. So far, most of the literature has used the Mundell (1961) model of optimum currency areas. ${ }^{4}$ In a seminal paper Bayoumi and Eichengreen (1993) have proposed a method to empirically measure the degree of business cycle comovements, in order to assess optimal currency areas, that can also be used to address the issue of fixed exchange rate regimes or full dollarization. Applying a procedure to decompose temporary and permanent shocks in a time series, the authors identify demand shocks as the transitory component of GDP. They find that the correlation among the demand shocks is not very high in the European Union and conclude that Europe might not be an optimum currency area (OCA), according to the OCA model of Mundell (1961). Related trend/cycle decompositions have been used for Central America by Fiess (2007), who also primarily focuses on the contemporaneous correlation of shocks, when evaluating the scope for macroeconomic policy coordination in Central America.

In our view, this approach provides only incomplete information to policy makers for several reasons. On the one hand, there may be permanent demand shocks or temporary supply shocks. It is therefore useful to also investigate the full time series in growth rates, rather than focusing on the

\footnotetext{
${ }^{1}$ See Figure 3.

${ }^{2}$ For example Berg, Borensztein, and Mauro (2002); Temprano-Arroyo (2003); Salvatore (2001); Alesina, Barro, and Tenreyro (2002) propose dollarization of the economies.

${ }^{3}$ Levy Yeyati and Sturzenegger (2002) give a review of the issue of dollarization; and Mishkin and Savastano (2001) give an overview of monetary policy options for Latin America, including currency boards and dollarization.

${ }^{4}$ An overview of the Mundell model is given in De Grauwe (1994). A formal analysis of exchange rate regime choice, based on the correlation of shocks, is also given in Berger, Jensen, and Schjelderup (2001).
} 
transitory elements only. More importantly, on the other hand, the contemporaneous correlation of the transitory component (or the full time series) may not be sufficient, as a basis for monetary policy coordination or a common currency. Even when the correlation of shocks between two countries is high, the response of each country to a shock - often interpreted as a business cycle can be very different. When one country reacts to and absorbs the shock more quickly than the other, it remains difficult to implement a common stabilization policy.

In order to address this issue, we investigate in the first part of our paper whether there exist common cyclical reactions to a standard shock in the Central American countries and the USA, using the test for common serial correlation that was first developed by Engle and Kozicki (1993) and Vahid and Engle (1993) and later extended by Cubadda $(1999,2007) .{ }^{5}$ The authors show that it is possible to test for common serial correlation (i.e. a common business cycle) by constructing a linear combination of the two time series (that each follow an $\mathrm{AR}(\mathrm{p})$-process) that is free of autocorrelation. If it is feasible to construct such a linear combination, it implies that there exists a common $\mathrm{AR}(\mathrm{p})$-structure, as well as a perfectly collinear response of two time series to a standard shock.

The existence of such a common reaction to shocks would be an ideal precondition for official dollarization in a Mundell (1961) framework. ${ }^{6}$ We will show, however, that this precondition is not convincingly met in any of the countries we studied. Despite the relatively high contemporaneous correlation of shocks, the different persistence of shocks would be a strong argument against official dollarization, rather than for it.

In the second part of the paper, we argue that the optimum currency area framework of Mundell (1961) also neglects some important characteristics of most middle income countries that may change the dollarization debate substantially: The Mundell framework is build on the assumption that a freely floating exchange rate would help to smooth asymmetric shocks. In the case of idiosyncratic business cycles, the exchange rate could then contribute to stabilize the economy. Schneider and Tornell (2004), however, argue that in the presence of credit market imperfections, a free floating exchange rate would amplify the business cycle fluctuations, rather than smooth them. Their argument is that in the presence of enforceability problems, agents will find it optimal to undertake risk to overcome their credit constraints. Tornell and Westermann (2002) document that

\footnotetext{
${ }^{5}$ See Urga (2007) for an overview of recent developments in the literature of common features in time series.

${ }^{6}$ This approach has been also used in the context of the policy debate on a common currency in North-East Asia by Cheung and Yuen (2005) (see section on further literature).
} 
many middle income countries have undertaken such risk by denominating their debt in US Dollars, thereby taking advantage of the lower interest rates in foreign currency. The consequences for the whole economy, when liabilities are denominated in foreign currency, is that a real appreciation will reduce the value of the debt and allow the agents to take on even more debt during the boom period. In the case of a depreciation, the value of the debt will increase and reduce the scope to finance further investment. Contrary to the Mundell assumption, the exchange rate does therefore not smooth the business cycle, but amplify it and generate the boom-bust cycle pattern that is also characteristic for many Central American economies. In a currency crisis, a very large depreciation, a large number of firms and banks can become bankrupt, in a partially dollarized economy - a possibility that has first been pointed out in the context of the dollarization debate by Calvo (2001).

We document in the second part of our paper that several characteristics of countries with boombust cycle patterns are present in Central America. A high dollarization of liabilities, relatively weak judicial institutions and credit constraints, particularly for small firms, are present in all countries. More subtle, but also informative - and an implication of the model on boom-bust cycles - is the fact that in recent years, a real appreciation has coincided with a high credit growth rate and an expansion of non-tradable sector's output relative to the tradable sector. Furthermore, most countries have already experienced systemic banking and currency crisis over the past 20-30 years. ${ }^{7}$

Finally, we attempt to uncover the impact of exchange rate movements on domestic output directly. Using a bivariate VAR, we find that in Central American countries there is indeed a positive reaction of GDP to an appreciation of the exchange rate and vice versa. We follow the identification approach of Tornell and Westermann (2005) to derive the impulse response functions and pool the reactions across countries in order to overcome the small sample problem. The evidence is confirmed also, when considering Mexico, for which a longer time series exists.

Our main policy conclusion is that official dollarization could be an important tool to achieve business cycle stabilization, but not because business cycles are similar to the US. In fact the full impulse response pattern is quite different, even for countries where the contemporaneous correlations are high. We argue instead that the main advantage derives from the fact that the mismatch between foreign currency liabilities and domestic revenues, in particular for small, non-

\footnotetext{
${ }^{7}$ See Table A.4 in the Appendix, and also Kaminsky and Reinhart (1998) who study financial crises in Latin America. In a later paper the authors analyze the links between banking and currency crises, the so called twin crises phenomenon (Kaminsky and Reinhart, 1999).
} 
tradable goods producing firms, can be avoided, as well as the pronounced cyclical movements and financial crisis that follow from exchange rate movements in its presence.

The next section contains the analysis of the dollarization question in the Mundell framework. In section three, the empirical analysis is guided by the boom-bust cycle framework of Schneider and Tornell (2004). Section 4 gives a review of the related literature, and the last section concludes.

\section{Mundell-Framework}

As a first approach, we will analyze the dollarization question in the context of the optimum currency area (OCA) framework (See Mundell (1961), McKinnon (1963), and Kenen (1969)). In this framework, the main loss associated with dollarization is the loss of individual monetary policy that helps to smooth asymmetric shocks. The more symmetric shocks are across countries, the smaller is this potential welfare loss. Tests for comovements (Bayoumi and Eichengreen (1993); Fiess (2007) among others) of business cycles are therefore a main empirical tool to assess the costs of policy coordination that a monetary union or an official policy of dollarization implies. In the following subsections we analyze various forms of comovement and argue that the methods that have been used so far only provide an incomplete picture for a reliable policy contribution.

\subsection{The Data and Descriptive Statistics}

The time series for the Central American countries, Belize, Costa Rica, Dominican Republic, El Salvador, Mexico, Nicaragua, and Panama, GDP real indices (seasonally adjusted) are obtained from the Latin American and Caribbean Macro Watch of the Inter-American Development Bank. Equivalent data for the USA were retrieved from the International Financial Statistics Database of the International Monetary Fund. For Guatemala we use the monthly index of economic activity from Banco de Guatemala ${ }^{8}$ and for Honduras the monthly index of industrial production (real and s.a.) from the Inter-American Development Bank. ${ }^{9}$ All series are re-based to 2001:1. In the following analysis, logarithmized growth rates of GDP will be studied in the longest common available sample, from 1997:1 to 2008:1.

Figure 1 displays the GDP series in levels and growth rates. The growth rates of Belize, Honduras, and Nicaragua stand out highly volatile. In many countries there have been slightly

\footnotetext{
${ }^{8}$ Data have been seasonally adjusted with the Census X12 method.

${ }^{9}$ For both countries quarterly GDP is not available. However, we use these indices as proxies for GDP and we will refer to both as "GDP" in the following.
} 
Figure 1: GDP levels and growth rates of Central American countries
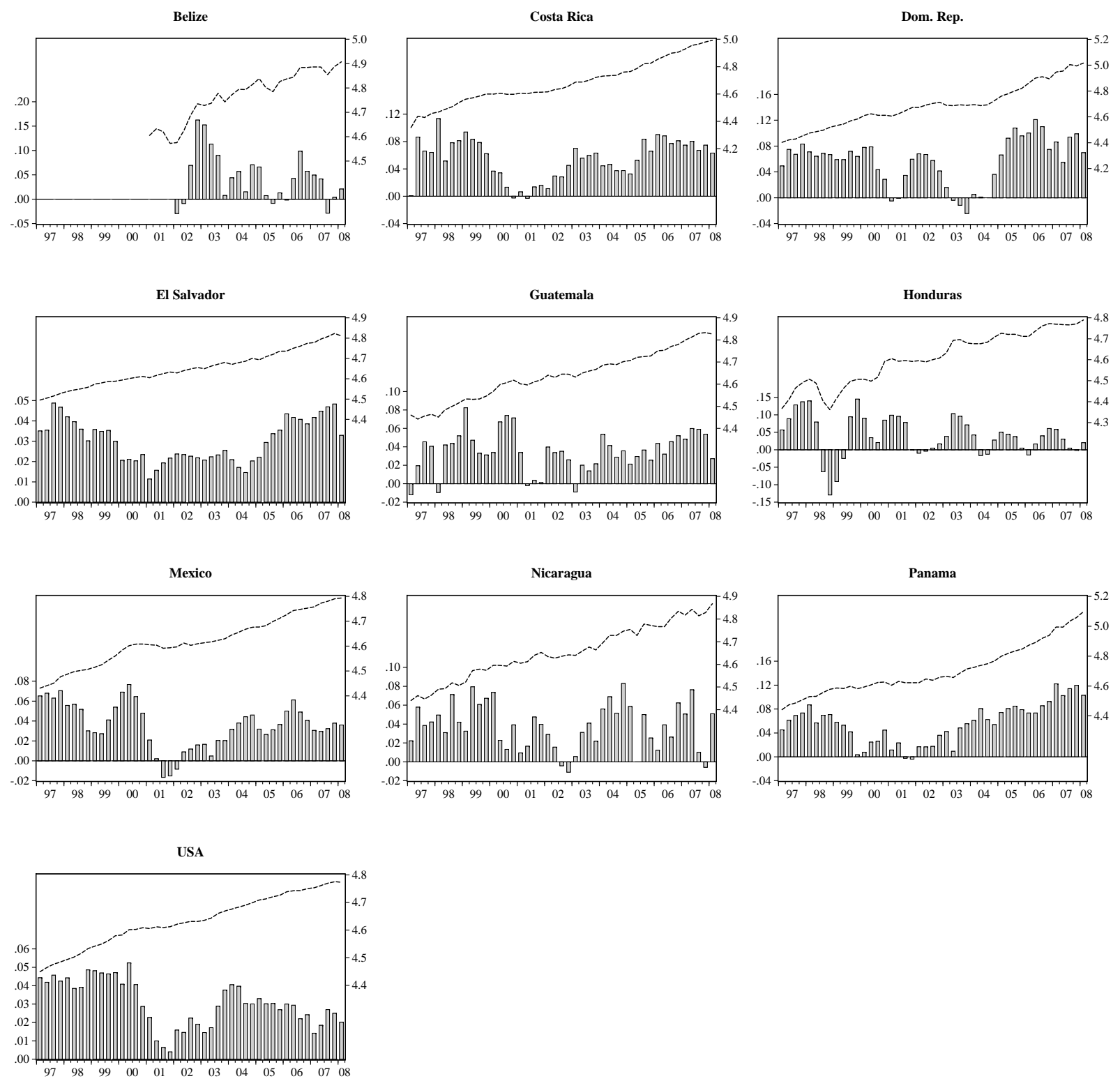

Note: GDP levels and growth rates of the Central American countries are displayed in quarterly data from 1997:1 to 2008:1. The growth rates are displayed on the left axis (bar charts), the levels on the right axis (dashed lines).

Source: Authors representation, based on IADB (2010), Banco de Guatemala, and IMF (2010).

negative growth rates in 2000/2001, e.g. in Costa Rica, Dominican Republic, Guatemala, Mexico and Panama. In the US growth has been nearly stagnating at this time. The common slowdown of the countries in the post 2001-period provides a first visual impression that some sort of comovement across business cycles exists vis-à-vis the United States, and across Central American countries.

Other periods with negative rates that are more idiosyncratic, can be explained with the occurrence of occasional banking and/or currency crisis, as in the Dominican Republic in 2003 (twin 
crisis), in Honduras in 1999 (banking crisis), and in Nicaragua in 2002 (banking crisis). ${ }^{10}$ On average, however, the growth rates of the Central American countries have been relatively high (compare Table 1) with mean growth rates between $3 \%$ and $6 \%$ annual growth. Many of the countries even have experienced boom-periods, prior to busts, with a maximum growth rate of more than 10\%, e.g. Belize, Costa Rica, Dominican Republic, Honduras, and Panama.

Table 1: Descriptive statistics of the GDP growth rates of Central American countries

\begin{tabular}{|c|c|c|c|c|c|c|c|c|c|c|}
\hline & Belize & Costa Rica & Dom. Rep. & $\begin{array}{c}\text { El } \\
\text { Salvador }\end{array}$ & Guatemala & Honduras & Mexico & Nicaragua & Panama & USA \\
\hline Mean & 0.044 & 0.054 & 0.056 & 0.030 & 0.035 & 0.039 & 0.036 & 0.038 & 0.056 & 0.031 \\
\hline Maximum & 0.163 & 0.113 & 0.121 & 0.049 & 0.082 & 0.145 & 0.077 & 0.083 & 0.122 & 0.052 \\
\hline Minimum & -0.029 & -0.003 & -0.024 & 0.011 & -0.012 & -0.129 & -0.017 & -0.011 & -0.004 & 0.004 \\
\hline Std. Dev. & 0.051 & 0.029 & 0.036 & 0.010 & 0.022 & 0.058 & 0.023 & 0.024 & 0.033 & 0.013 \\
\hline Obs. & 25 & 45 & 45 & 45 & 45 & 45 & 45 & 45 & 45 & 45 \\
\hline
\end{tabular}

Note: Descriptive statistics of the GDP growth rates of the Central American countries are displayed in quarterly data from 1997:1 to 2008:1 (the sample for Belize is shorter due to data availability).

Source: Authors calculations, based on IADB (2010), Banco de Guatemala, and IMF (2010).

In order to get a first quantitative impression of the similarity of the business cycles in the Central American countries and the USA, we look at the contemporaneous correlations of the GDP growth rates that are displayed in Table 2.

Table 2: Contemporaneous correlations between the GDP growth rates of Central American countries and the USA

\begin{tabular}{|c|c|c|c|c|c|c|c|c|c|}
\hline \multicolumn{10}{|c|}{ 1997:1 - 2008:1 (pairwise samples ) } \\
\hline & Belize & Costa Rica & Dom. Rep. & $\begin{array}{c}\text { El } \\
\text { Salvador }\end{array}$ & Guatemala & Honduras & Mexico & Nicaragua & Panama \\
\hline Belize & 1 & & & & & & & & \\
\hline Costa Rica & 0.004 & 1 & & & & & & & \\
\hline Dom. Rep. & -0.375 & 0.446 & 1 & & & & & & \\
\hline El Salvador & -0.350 & 0.696 & 0.691 & 1 & & & & & \\
\hline Guatemala & -0.474 & 0.155 & 0.257 & 0.247 & 1 & & & & \\
\hline Honduras & 0.430 & -0.130 & -0.171 & 0.019 & -0.370 & 1 & & & \\
\hline Mexico & -0.097 & 0.297 & 0.367 & 0.416 & 0.307 & 0.202 & 1 & & \\
\hline Nicaragua & -0.035 & 0.241 & -0.014 & 0.054 & 0.069 & 0.084 & 0.238 & 1 & \\
\hline Panama & -0.311 & 0.623 & 0.417 & 0.686 & 0.284 & -0.191 & 0.320 & 0.108 & 1 \\
\hline USA & -0.229 & 0.326 & 0.119 & 0.234 & 0.328 & 0.006 & 0.731 & 0.301 & 0.119 \\
\hline
\end{tabular}

Note: Contemporaneous correlations between the (logarithmized) GDP growth rates of Central American countries and the USA are displayed. All pairwise samples with Belize are 2002:1 - 2008:1; the remaining samples start in 1997:1.

Source: Authors calculations, based on IADB (2010), Banco de Guatemala, and IMF (2010).

All GDP growth rates, excepting the Belizean one - which has a negative correlation with the

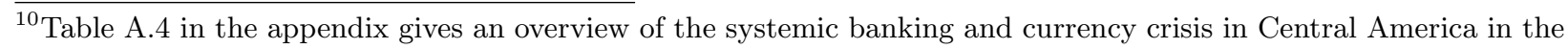
last decades.
} 
US, and the growth rate of Honduras, where the correlation is nearly zero -, are positively correlated with the GDP growth rate of the USA. The contemporaneous correlation between Mexico and the US is with 0.73 especially high, which reflects the close economic relationship between the two NAFTA-countries. ${ }^{11}$ Among the remaining Central American countries, Costa Rica, Guatemala, and Nicaragua have the highest correlations with $0.33(0.33,0.30)$, which are still significantly higher than the correlations between the US GDP growth rate and the German or Japanese ones (0.26 and -0.01). The two dollarized economies Panama and El Salvador, however, have a weaker correlation with the US, with a value of 0.12 and 0.23 , respectively. ${ }^{12}$

This relatively high correlation of business cycles is often interpreted as a precondition being fulfilled to introduce a policy of official dollarization at a relatively low cost in terms of stabilization policy. Our first main point is, however, that not only the correlation of shocks, but also the reactions to the shocks over time are important. As a first pass, we illustrate this point, by displaying the autocorrelation functions of the GDP growth rates in Figure 2. Although in some cases the reaction in the first quarters is quite similar, we find that after some time the functions differ substantially, both with respect to the magnitude and to the length of the reaction that each country has to a standard shock. Clearly this asymmetric adjustment will pose further difficulties for monetary policy under a common currency. In the following section, we will test more formally, whether the first visual impression is confirmed and cyclical reactions to shocks are indeed significantly different between the countries.

\subsection{A Test for Common Cycles and Codependence}

In this section we implement a formal test for various types of comovement between the Central American economies and the United States. We start with the unusual preliminary exercises, on the stationarity properties of the time series in levels and first differences and on cointegration. We then conduct a test for common cycles between Central American countries and the United States, using the test for common serial correlation, developed by Engle and Kozicki (1993). The intuition for this test is the following: If both the first differences of country $i$ and country $j$ are stationary $\operatorname{AR}(p)$ time series, a linear combination should exist that has a reduced $\operatorname{AR}(0)$ structure, if the

\footnotetext{
${ }^{11}$ The correlation between Canada and the US is quite similar with 0.77. Correlations among the Eurozone countries are slightly smaller, e.g. among Germany and France 0.58 and among Germany and Italy 0.72.

${ }^{12}$ Goldfajn, Olivares, Frankel, and Milesi-Ferretti (2001) analyze the disadvantages and advantages of dollarization on the example of Panama, one of the largest dollarized economies in the world, comparing the country especially with Costa Rica and Argentina to control for idiosyncratic effects.
} 
Figure 2: Autocorrelation functions of GDP growth rates of Central American countries and the US
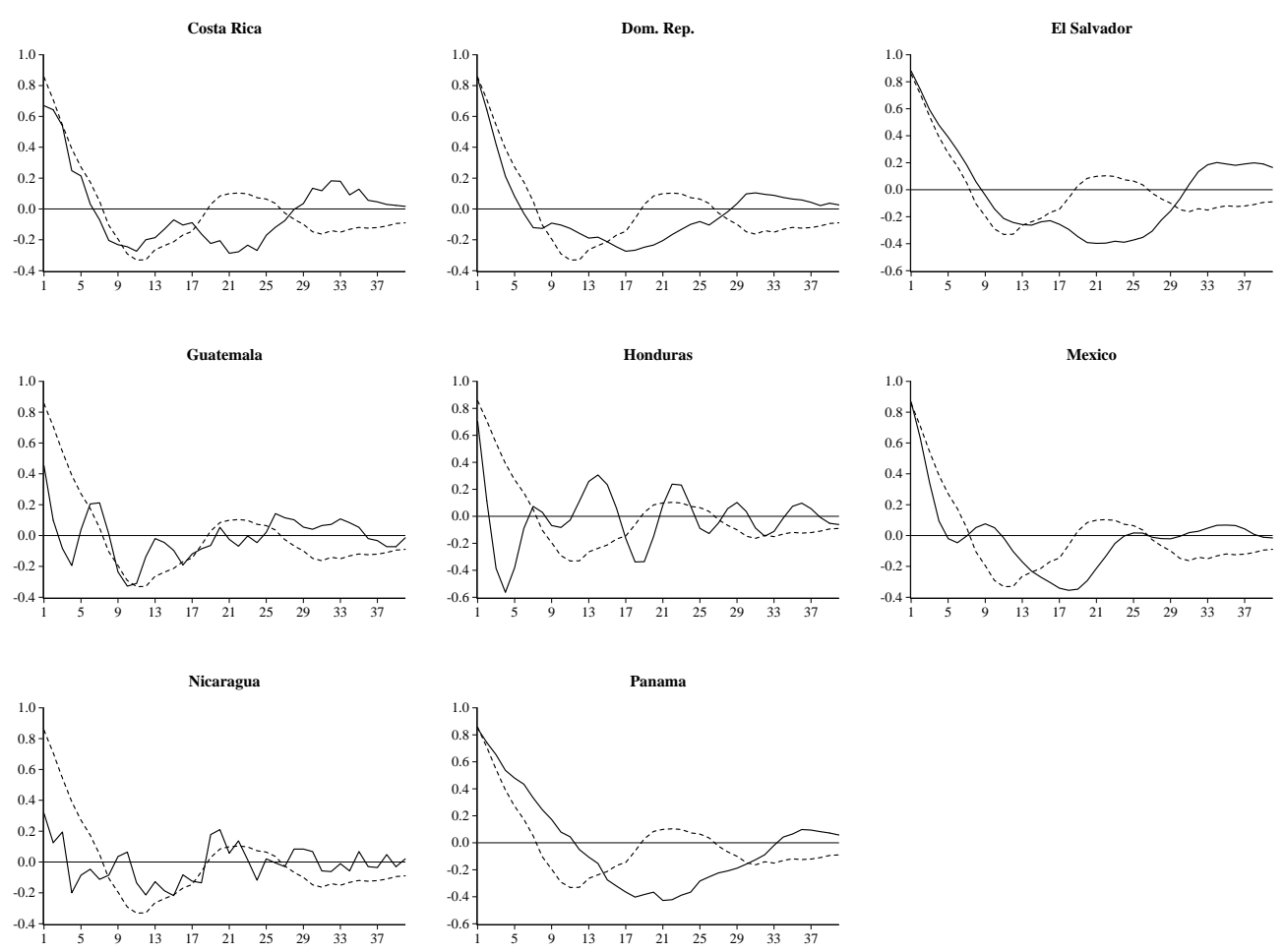

Note: The autocorrelation functions of the logarithmized growth rates of the GDP of the Central American countries (solid line) and the USA (dashed line) are displayed in the sample 1997:1 - 2008:1.

Source: Authors calculations, based on IADB (2010), Banco de Guatemala, and IMF (2010).

reaction to shocks is the same across countries. Even if the contemporaneous correlation of growth rates is quite high, as it was shown to be the case in several countries in the previous section, the two countries do not need to respond similarly to shocks. We therefore argue that the application of the test for common features - with regard to both trend and cycles in GDP - provides a more complete picture to understand the comovements of business cycles across countries, and to evaluate the potential costs of the loss of an autonomous monetary policy.

Stationarity As a first preliminary analysis, we test for the stationarity of the time series, using the Augmented-Dickey-Fuller (ADF) test:

$$
\Delta y_{t}=\mu+\gamma y_{t-1}+\sum_{j=1}^{p} \phi_{j} \Delta y_{t-j}+\epsilon_{t}
$$


where $y_{t}=$ GDP at time $t^{13}, p=$ the lag parameter, $\epsilon_{t}=$ an innovation term, and $\Delta$ is the first difference operator. The lag parameter $p$ is determined by the Schwarz information criterion (SIC) and the finite sample critical values from Cheung and Lai (1995) are used. The results of the ADF test are displayed in Table A.1 in the Appendix. For all countries, the null of non stationarity cannot be rejected in levels and can be rejected in first differences, hence all series are I(1). ${ }^{14}$

Cointegration As a second step, we examine whether there exist common long run trends, by implementing the test for cointegration using the Johansen $(1988,1991)$ maximum likelihood approach, and allowing for an intercept in the cointegrating equations:

$$
Y_{t}=\mu+\sum_{i=1}^{p-1} \Gamma_{i} Y_{t-i}+\epsilon_{t}
$$

where $Y_{t}$ is a $2 \times 1$ vector of the GDP series, $\mu$ is an intercept vector, and $\epsilon_{t}$ is a vector of innovation terms.

The canonical correlations between the least squares residuals of the two subsequent regressions are calculated in order to deduce the maximum eigenvalue test statistic:

$$
\begin{aligned}
\Delta Y_{t} & =\mu_{1}+\sum_{i=1}^{p-1} \Gamma_{i} \Delta Y_{t-i}+\epsilon_{1 t} \\
\text { and } \quad Y_{t-p} & =\mu_{2}+\sum_{i=1}^{p-1} \Gamma_{i} \Delta Y_{t-i}+\epsilon_{2 t} .
\end{aligned}
$$

The null hypothesis of the maximum eigenvalue statistic claims that there are $r$, and the alternative hypothesis that there are $r+1$ cointegrating vectors:

$$
\text { Maximum Eigenvalue Statistic }=-T \ln \left(1-\lambda_{r+1}\right)
$$

The critical values of Osterwald-Lenum (1992), corrected with the scaling factor of Cheung and Lai (1993) to control for a possible finite-sample bias, are then compared with the calculated test statistics.

The results are shown in Table A.2 in the Appendix. We find that the GDP series of the Dominican Republic, El Salvador, Guatemala, and Honduras are cointegrated with the US GDP.

\footnotetext{
${ }^{13}$ We do the test both in logarithmized levels and in logarithmized growth rates.

${ }^{14}$ For El Salvador the lag length of the ADF-test in first differences has been manually selected.
} 
For these countries, we include an error correction in the computation of the following test statistics for common cycles.

Common Serial Correlation Finally, we conduct the test for common serial correlation. We start with the two-stage least squares (TSLS) approach of Engle and Kozicki (1993). The first regression

$$
y_{i, t}=c+\beta y_{j, t}+\epsilon_{t}
$$

is estimated with TSLS, including as instruments all lagged variables of $y_{i}$ and $y_{j}{ }^{15}$, i.e. $y_{i, t-k}$ and $y_{j, t-k}$ for $k=1, \ldots, p$ as well as the lagged error correction terms, $e c_{t-k}$, where it is needed. $(1, \beta)$ is the normalized common feature vector. ${ }^{16}$

Then, we analyze whether the estimated residual $\hat{\epsilon}_{t}$ still contains autocorrelation that affects the present values through the same channels as $y_{i, t}$ and $y_{j, t}$ by estimating the following equation:

$$
\hat{\epsilon_{t}}=c+\sum_{k=1}^{p} \delta_{k} y_{i, t-k}+\sum_{k=1}^{p} \gamma_{k} y_{j, t-k}+\sum_{k=1}^{p} \phi_{k} e c_{t-k}+u_{t}
$$

The null hypothesis is defined as all parameters being not statistically different from zero. If all lagged variables do not explain the estimated residual, the common $\operatorname{AR}(\mathrm{p})$-pattern has been removed in the first regression. $H_{0}$ is tested with the F-statistic:

$$
F_{k-1, T-k}=\frac{R^{2}}{1-R^{2}} \frac{T-k}{k-1}
$$

where $T$ denotes the number of observations and $k$ refers to the number of restrictions, i.e. the number of exogenous variables including the constant. $R^{2}$ is the R-squared of regression 2. Thus, if the null hypothesis cannot be rejected, evidence in favor of a common cycle is established.

Results of the serial correlation common feature test (with TSLS estimation) are displayed in panel A of Table 3. In column CF, we see that a serial correlation common feature is found only for Nicaragua, where the null of a common feature cannot be rejected at the $1 \%$ or $5 \%$ level and the serial correlation common feature vector is statistically significant.

As a robustness check, we also conduct the test with an optimal general method of moments

\footnotetext{
${ }^{15} y_{i}$ and $y_{j}$ refer to the logarithmized growth rates of GDP.

${ }^{16}$ In order to generate the best condition for finding cyclical comovement, we choose the most parsimonious lag structure that is sufficient to remove all autocorrelation from the residuals. However, using the AIC or SIC criterion to choose the lag length does not change the results qualitatively.
} 
Table 3: Results of serial correlation common feature and codependence tests

\begin{tabular}{|c|c|c|c|c|c|c|}
\hline \multicolumn{7}{|l|}{ PANEL A: TSLS } \\
\hline & \multicolumn{6}{|c|}{ 1997:1 - 2008:1 } \\
\hline & \multirow[b]{2}{*}{$\mathrm{p}$} & & & \multicolumn{3}{|c|}{ Codependence of order } \\
\hline & & & CF & 1 & 2 & 3 \\
\hline \multirow[t]{2}{*}{ Costa Rica } & 2 & test-statistic & $6.57 * * *$ & 2.71 & & \\
\hline & & vector & $0.20 * *$ & $0.20 * *$ & & \\
\hline \multirow[t]{2}{*}{ Dominican Rep. } & 1 & test-statistic & $69.71 * * *$ & & & \\
\hline & & vector & 0.04 & & & \\
\hline \multirow[t]{2}{*}{ El Salvador } & 1 & test-statistic & $66.80 * * *$ & & & \\
\hline & & vector & 0.30 & & & \\
\hline \multirow[t]{2}{*}{ Guatemala } & 1 & test-statistic & $16.43 * * *$ & & & \\
\hline & & vector & $0.55 * * *$ & & & \\
\hline \multirow[t]{2}{*}{ Honduras ${ }^{\text {a) }}$} & 9 & test-statistic & $9.70 * * *$ & $6.12 * * *$ & $4.71 * * *$ & $3.71 * *$ \\
\hline & & vector & 0.10 & 0.10 & 0.10 & 0.10 \\
\hline \multirow[t]{2}{*}{ Mexico } & 3 & test-statistic & $3.17 * *$ & 0.42 & 0.67 & \\
\hline & & vector & $0.44 * * *$ & $0.43 * * *$ & $0.43 * * *$ & \\
\hline \multirow[t]{2}{*}{ Nicaragua } & 1 & test-statistic & 0.59 & & & \\
\hline & & vector & $1.16 * *$ & & & \\
\hline \multirow[t]{2}{*}{ Panama } & 4 & test-statistic & $4.67 * * *$ & $2.54 * *$ & $3.09 * *$ & 3.04 \\
\hline & & vector & 0.04 & 0.04 & 0.04 & 0.04 \\
\hline
\end{tabular}

PANEL B: GMM

\begin{tabular}{|c|c|c|c|c|c|c|}
\hline & \multicolumn{3}{|c|}{ 1997:1 - 2008:1 } & \multicolumn{3}{|c|}{ Codependence of order } \\
\hline & $\mathrm{p}$ & & $\mathrm{CF}$ & 1 & 2 & 3 \\
\hline \multirow[t]{2}{*}{ Costa Rica } & 2 & test-statistic & $27.64 * * *$ & $15.10^{* * *}$ & & \\
\hline & & vector & $-0.23 * * *$ & $-0.15 * *$ & & \\
\hline \multirow[t]{2}{*}{ Dominican Rep. } & 1 & test-statistic & $29.59 * * *$ & & & \\
\hline & & vector & -0.09 & & & \\
\hline \multirow[t]{2}{*}{ El Salvador } & 1 & test-statistic & $28.63 * * *$ & & & \\
\hline & & vector & $-0.40 * *$ & & & \\
\hline \multirow[t]{2}{*}{ Guatemala } & 1 & test-statistic & $27.23 * * *$ & & & \\
\hline & & vector & -1.01 & & & \\
\hline \multirow[t]{2}{*}{ Honduras $^{\text {a) }}$} & 9 & test-statistic & $33.62 * * *$ & $12.49 * * *$ & $6.30 *$ & 2.66 \\
\hline & & vector & -0.28 & -0.43 & -0.77 & -2.22 \\
\hline \multirow[t]{2}{*}{ Mexico } & 3 & test-statistic & $16.76 * * *$ & 6.62 & 2.19 & \\
\hline & & vector & $-0.40 * * *$ & $-0.37 * * *$ & $-0.37 * * *$ & \\
\hline \multirow[t]{2}{*}{ Nicaragua } & 1 & test-statistic & $21.36 * * *$ & & & \\
\hline & & vector & $-0.33 * * *$ & & & \\
\hline \multirow[t]{2}{*}{ Panama } & 4 & test-statistic & $27.79 * * *$ & $11.31 * *$ & 8.23 & 2.29 \\
\hline & & vector & $-0.22 * * *$ & $-0.26 * * *$ & -0.18 & $-0.36 * * *$ \\
\hline
\end{tabular}

Note: Results of the TSLS estimation (panel A) and GMM estimation (panel B) of serial correlation common features and codependence between the GDP growth rates of the Central American countries and the USA are reported for the sample 1997:1 - 2008:1. In the rows test statistic F-statistics are reported in panel A and $X^{2}$-statistics are reported for the GMM approach (panel B). The rows titled vector report the coefficient $\beta$ of the common feature vector. ***, ** indicates the rejection of the null hypothesis with a significance of $1 \%, 5 \%$. a) To test for a common feature with Honduras, industrial production instead of GDP has been used for the USA.

Source: Authors calculations, based on IADB (2010), Banco de Guatemala, and IMF (2010).

(GMM) estimation as proposed by Cubadda (1999, 2007), who argues that GMM is more appropriate for testing for common cycles, due to its relative efficiency. Panel B in Table 3, Column CF, shows that with this alternative estimation method, none of the countries share a common serial correlation feature with the United States. 
Codependence Some time series may have a different initial response to a shock, but a common response after some lags. This weaker form of cyclical, but non-synchronized comovement, called codependence, was first described by Gourieroux and Peaucelle (1989) and Vahid and Engle (1997). We test for codependence estimating the same equations as for the SCCF: 1. TSLS (equation 1) and 2. OLS of the residual (equation 2). Then, we compute a Wald-Test, testing whether all but the first lagged terms of both interest rates do not explain jointly the estimated residual $\hat{\epsilon}_{t}$.

Codependence of order one, i.e. a synchronized reaction to a common shock after one period, is found for Costa Rica and Mexico. The remaining countries reject the null hypothesis of a common feature. Using the optimal GMM test proposed by Cubadda (1999, 2007), we can only confirm the codependence of order one between Mexico and the US, and we find codependence of order three for Panama (see panel B in Table 3).

Interestingly, there is no obvious difference between countries that intend to dollarize, and those who already have officially dollarized their economies, like Panama and El Salvador. This suggests that there is not much endogeneity between the exchange rate regime and the degree of business cycle comovement.

Finally, as a last robustness check, we disregard the requirement of common lag structures and conduct the TSLS serial correlation common feature test with four lags in the estimation equations. When conducting the test with 4 lags in each estimation equation, results remain qualitatively unchanged (see Table A.3 in the Appendix). The only country for which we find a robust evidence in favor of codependence - that holds in all specifications of the test - is Mexico.

\section{Schneider/Tornell-Framework}

Based on the results of the previous section an official dollarization of the Central American economies seems to be associated with substantial costs, as asymmetric shocks, as well as common shocks with asymmetric persistence cannot easily be offset by domestic stabilization policy, such as a depreciation against the US Dollar to stimulate exports. In this section we will show that it is not clear, whether this indeed constitutes a welfare loss in the presence of credit market imperfections. Schneider and Tornell (2004) have proposed a conceptual framework, where dollarization and currency mismatch arise as a consequence of contract enforceability problems and bailout expectations. In this model, the exchange rate plays just the opposite role. Rather than stabilizing the business cycle, it amplifies cyclical fluctuations. In their model firms denominate their debt in 
foreign currency in order to overcome credit constraints. The revenues of the non-tradable goods producing sector, however, are still in domestic currency. In this setting, a real appreciation reduces the debt burden of the firms and allows them to take on even more debt, as their net worth has increased. A real depreciation, on the other hand, leads to an increase of the debt burden and a reduction in net worth. A very large depreciation - such as in a currency crisis - will therefore lead to widespread bankruptcies. Overall, their model explains the patterns of boom-bust cycles that many middle income countries have experienced over the past decades.

We will document in the following subsections, that several of the characteristics of middle income countries that give rise to boom-bust cycle patterns are clearly present in the Central American economies.

Figure 3: Percentage of foreign-currency denominated liabilities

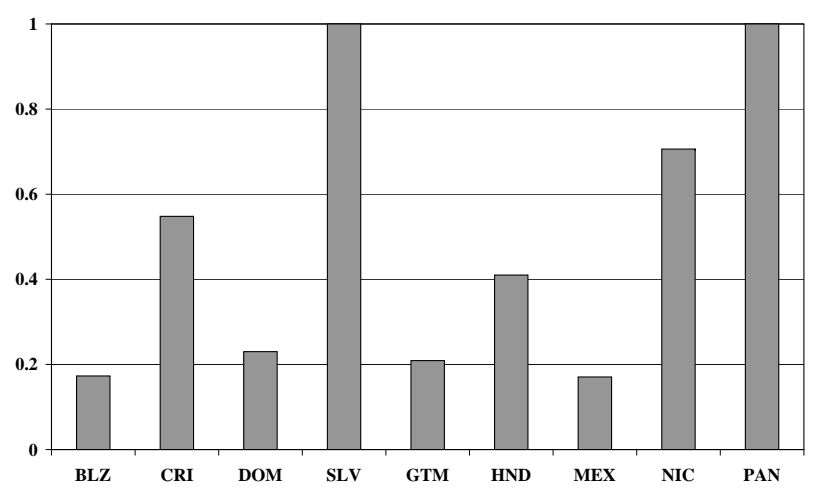

Note: Percentages of foreign-currency denominated liabilities in 2007 are reported. El Salvador has been dollarized in 2001, Panama uses the US\$ as currency since 1904.

Source: Authors representation, based on Caprio et al. (2008), Bank Regulation and Supervision Database, World Bank.

Currency Mismatch Figure 3 displays the percentages of foreign-currency denominated liabilities. Besides El Salvador and Panama, that use the US\$ as official currency since 2001 (1904), especially Costa Rica and Nicaragua display a high degree of unofficial dollarization with percentage shares of $54.80 \%$ and $70.60 \%$. In Honduras the de facto dollarization is still high with $41 \%$. The smallest degree of unofficial dollarization can be observed in Mexico with only $17.06 \%$.

In the model of Schneider and Tornell (2004), foreign currency financing is the consequence of institutional problems and credit constraints. Firms opt for a foreign currency loan that they can obtain at a lower interest rate despite the associated risk, because they expect a bailout in case of a systemic crisis. 
Figure 4: Rule of law

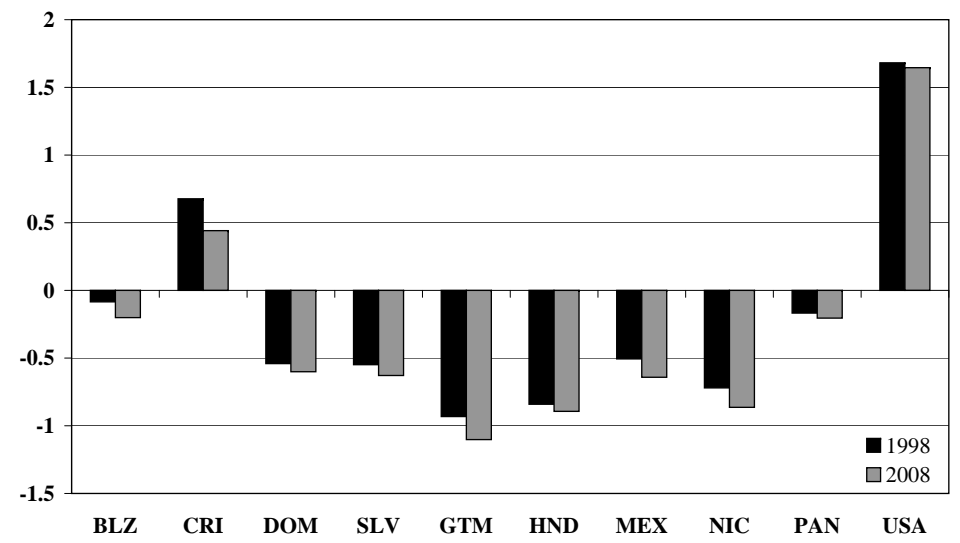

Note: The indicator "rule of law" measures the extent to which agents have confidence in and abide by the rules of society, in particular the quality of contract enforcement, the police, and the courts, as well as the likelihood of crime and violence. Indicators for 1998 and 2008 are reported. The range of the indicator is from -2.5 to 2.5 , with higher values corresponding to better governance outcomes.

Source: Authors representation, based on World Bank, Kaufmann, Kraay and Mastruzzi (2009).

Contract Enforceability Problems In Figure 4 the index rule of law, which measures the extent to which agents have confidence in and abide by the rules of society, in particular the quality of contract enforcement, the police, and the courts, as well as the likelihood of crime and violence, is displayed for the Central American countries and the US. The index varies from -2.5 to 2.5 , with higher values corresponding to better government outcomes. As can be seen easily, a high discrepancy between the situation in the US and the Central American countries exists. In 2008 the index has the value 1.65 in the United States, followed by Costa Rica with a value of only 0.44. The poorest outcome (-1.1) can be assigned to Guatemala. This difference means, for example, that enforcing contracts in 2008 took in the US about 300 days, in Costa Rica about 877 days, and in Guatemala 1459 days ${ }^{17}$.

Credit Constraints The importance of credit constraints can be illustrated in a descriptive analysis of enterprise surveys conducted by the World Bank among Central American firms. Table 4 shows in panel A the percentage of subgroups of financial constrained firms and in panel B the total number of firms (both constrained and not constrained). As the number of firms is rather low, the interpretations have to be handled quite carefully. However, some general features can be concluded from the data: Small firms are typically more credit constrained than medium and large

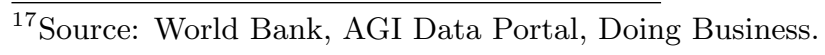


Table 4: Access to financing

PANEL A: percentage of financial constrained firms

\begin{tabular}{|c|c|c|c|c|c|c|c|c|}
\hline & total & small & medium & large & exporter & $\begin{array}{c}\text { non- } \\
\text { exporter }\end{array}$ & T-sector & N-sector \\
\hline Costa Rica & 73.76 & 74.79 & 66.15 & 80.56 & 78.26 & 72.63 & 73.52 & 77.27 \\
\hline Dom. Rep. & 28.89 & na & na & na & 20.00 & 29.30 & na & na \\
\hline El Salvador & 24.24 & 30.88 & 24.80 & 11.04 & 21.60 & 25.05 & 27.41 & 17.70 \\
\hline Guatemala & 18.97 & 26.22 & 14.74 & 11.21 & 12.82 & 20.74 & 22.56 & 12.89 \\
\hline Honduras & 25.00 & 34.74 & 19.55 & 10.00 & 9.38 & 27.69 & 26.62 & 22.54 \\
\hline Mexico & 18.51 & 20.24 & 16.96 & 16.55 & 18.92 & 18.47 & 20.07 & 12.85 \\
\hline Nicaragua & 22.38 & 24.73 & 20.26 & 15.22 & 23.53 & 22.25 & 23.84 & 17.70 \\
\hline Panama & 9.27 & 11.01 & 7.22 & 6.76 & 5.15 & 10.06 & 8.23 & 9.97 \\
\hline
\end{tabular}

PANEL B: number of firms

\begin{tabular}{lcccccccc} 
& & & & & & non- \\
exporter & T-sector & N-sector \\
\hline Costa Rica & 343 & 242 & 65 & 36 & 69 & 274 & 321 & 22 \\
Dom. Rep. & 225 & na & na & na & 10 & 215 & na & na \\
El Salvador & 693 & 285 & 254 & 154 & 162 & 531 & 467 & 226 \\
Guatemala & 522 & 225 & 190 & 107 & 117 & 405 & 328 & 194 \\
Honduras & 436 & 213 & 133 & 90 & 64 & 372 & 263 & 173 \\
Mexico & 1480 & 736 & 448 & 296 & 148 & 1332 & 1161 & 319 \\
Nicaragua & 478 & 279 & 153 & 46 & 51 & 427 & 365 & 113 \\
Panama & 604 & 336 & 194 & 74 & 97 & 507 & 243 & 361 \\
& & & & & & & & \\
\hline
\end{tabular}

Note: The company-level data for El Salvador, Guatemala, Honduras, Mexico, Nicaragua, and Panama are from 2006 and are based on the same standardized questionnaire. Data for Costa Rica and Dominican Republic are from 2005. However, the questionnaires differ. Company-level data for Belize (and also for the US) do not exist.

In panel A the percentage of financial constrained firms and in panel B the absolute number of firms (i.e. the sum of all firms in this category whether constrained or not) are displayed. A firm is defined as financially constrained if access to financing, which includes availability and cost, is a major or a very severe obstacle. A firm is defined as small if the number of employees lies between 5 and 19; as medium if the number is between 20 and 99; and as large if there are more than 100 employees (for Costa Rica the definition differs: small: 1-30; medium: 31-100; large: more than 101). A firm is defined as exporter if less than $85 \%$ percent of the establishment's revenues are from national sales. A firm is defined as T-sector-firm if the screener sector is manufacturing (i.e. foods, garments, textiles, machinery and equipment, chemicals, electronics, non-metallic minerals, other manufacturing); and as N-sector-firm if the sector is services (i.e. retail sale, IT, other services) or others (i.e. construction and transport) (for Costa Rica the definition differs: a firm is defined as T-sector-firm if the percentage of revenues from the manufacturing sector is bigger than the percentage of revenues from the sum of comercio, servicios and otros).

Source: Authors calculations, based on World Bank, Enterprise Surveys (2010).

firms, whereby a small firm is defined as having between 5 and 19 employees. In most countries, non-exporting firms are more constrained than exporting firms, whereby a firm is defined as exporter if less than 85 percent of its revenues are from national sales.

A Real Appreciation Another factor, that strengthens the risk for a boom-bust-cycle is a real appreciation, as it raises the risk of a depreciation that would at the same time augment the credit burden in the Central American country. As can be observed in Figure 5, that displays the real 
Figure 5: Real exchange rate vis-à-vis the US\$

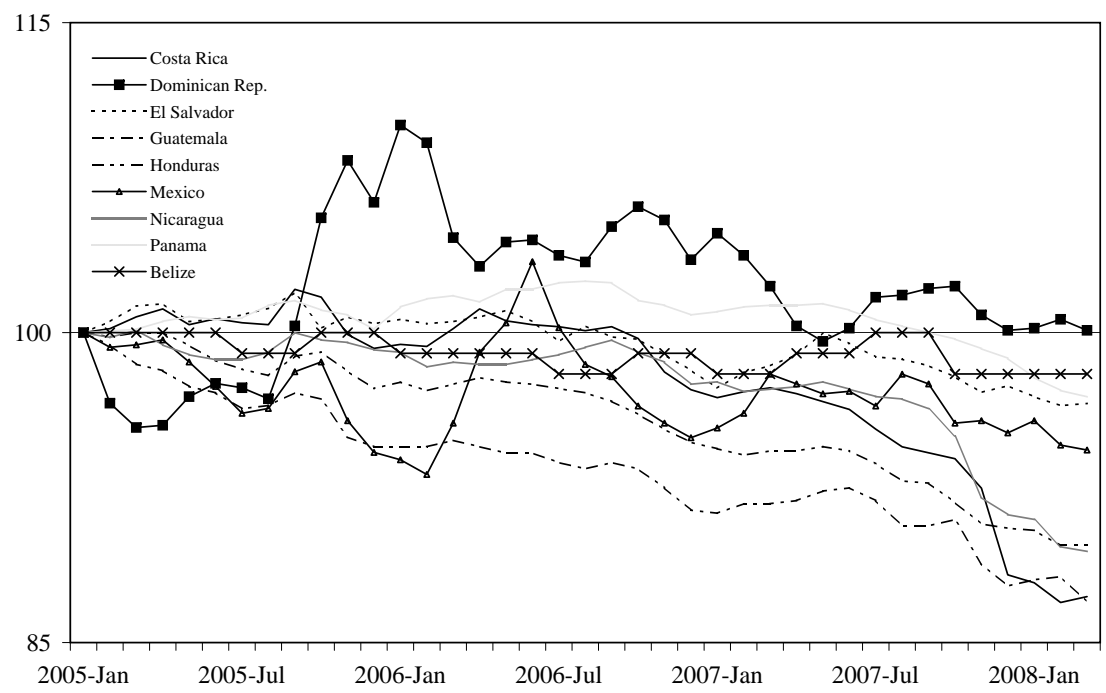

Note: Real exchange rates vis-à-vis the US\$ are displayed for the period 2005 - 2008. Data for Belize is quarterly; for all other countries monthly data is used.

Source: Authors representation, based on IADB (2010), Latin American and Caribbean Macro Watch.

exchange rates vis-à-vis the US\$, a real appreciation has taken place in almost all countries (with the exception of Belize), especially since mid-2006. Thus, the fear of a reversal with a following real depreciation is justifiable.

Figure 6: (Average) annual credit growth

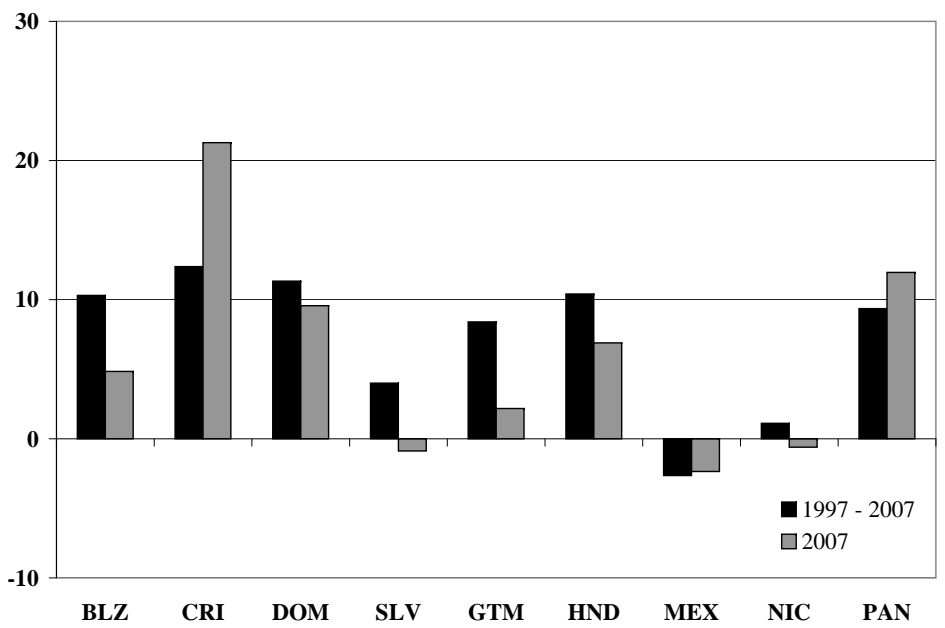

Note: (Average) annual growth rates of real domestic credit (in local currency) are displayed. Growth rates are expressed in percentages. For comparison: the average annual growth rate in the US between 1997 and 2007 has been $5.64 \%$.

Source: Authors calculations, based on WDI (2010). 
Credit Growth The observed real appreciation is especially alarming, if the credit volume has increased significantly during the last years, as more agents would be exposed to a suddenly increasing credit burden. Figure 6 shows the average annual growth rates of real domestic credit between 1997 and 2007 as well as the growth rate of 2007 .

Considering that the average annual growth rate of domestic credit has been about $5.64 \%$ in the US in the same sample, credit has grown at a considerable rate in many of the Central American countries. Particularly, in Costa Rica credit has grown enormously with an average rate of $12.38 \%$ per year. Also in Belize, the Dominican Republic and Honduras credit growth has been remarkable with an average of over $10 \%$ per year. However, there have been lending booms in all Central American countries (excepting Mexico and Nicaragua) during the sample period. ${ }^{18}$ Especially Costa Rica, the Dominican Republic and Honduras have gone through sustained boom phases: Costa Rica had a lending boom from 2000 to 2003, and 2005 to 2007, the Dominican Republic from 1997 to 1999, in 2001, and from 2005 to 2006, and Honduras from 1999 to 2000, in 2002, and from 2004 to 2006.

Sectoral Growth Middle income economies, experiencing boom-bust cycles, often display a very unequal development of the tradable's and the non-tradable's sector. Typically, the non-tradable's sector grows at a higher level than the tradable's sector. As can be observed in Figure 7, that displays the share of the non-tradable sector in total gross value added, this is especially true for Guatemala and Honduras. But also in Costa Rica and the Dominican Republic the share of the non-tradable's sector has increased in the last years.

The Role of the Real Exchange Rate We conclude this section by directly estimating the impact of real exchange rate movements on the business cycle. We implement a vector autoregressive (VAR) framework, to which Tornell and Westermann (2005) have given a structural interpretation in the context of a two-sector economy with contract enforceability problems and bailout expectations. The bivariate VAR includes GDP and the real exchange rate. The estimation model is

$$
\Delta Y_{t}=c+\sum_{i=1}^{p} A \Delta Y_{t-i}+\epsilon_{t}
$$

\footnotetext{
${ }^{18} \mathrm{~A}$ lending boom is defined for year $t$ if the average annual growth rate of domestic credit of the years $t$ and $t+1$ is more than $10 \%$.
} 
Figure 7: Shares of N-sector in total gross value added
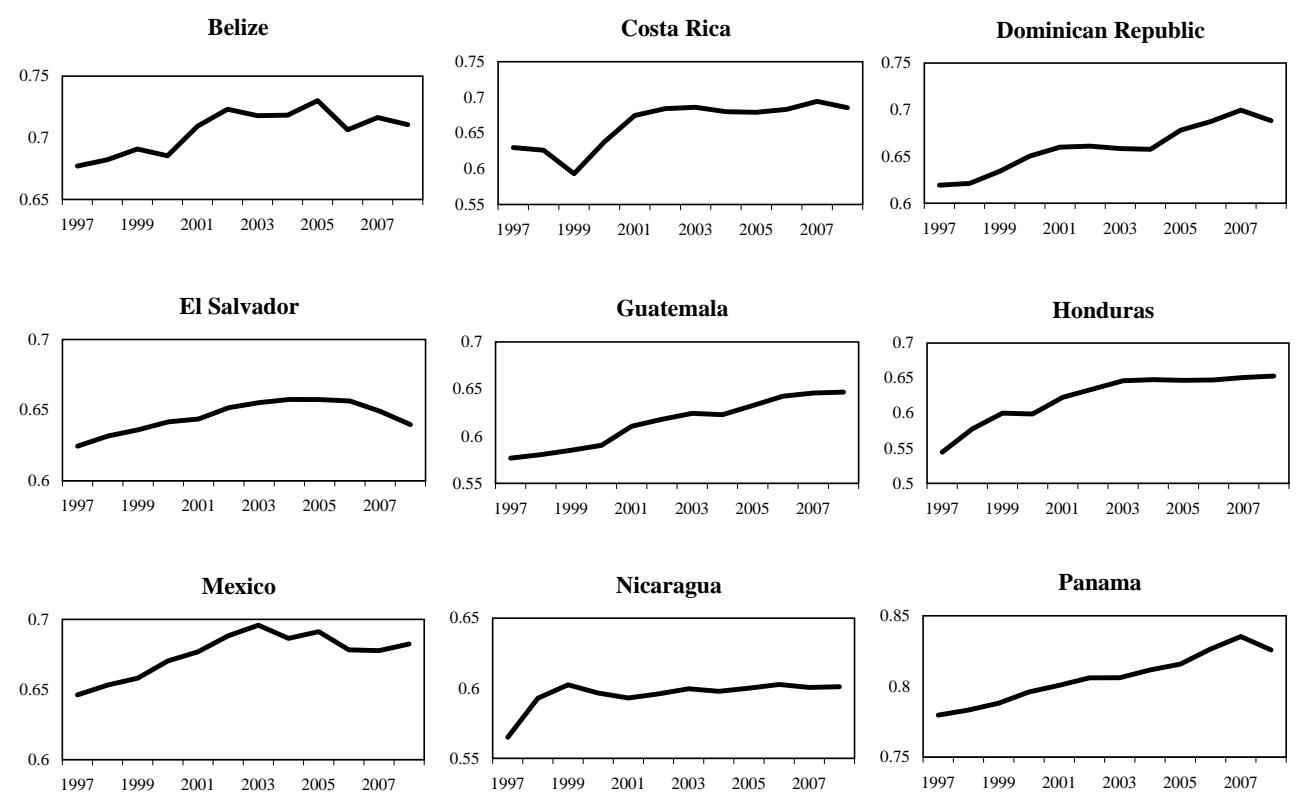

Note: The displayed line represents the share of the non-tradable sector in total gross value added. Tradable and non-tradable sector sum up to 1 . The tradable sector is defined by "Agriculture, hunting, forestry, fishing (ISIC A-B)" and "Mining, Manufacturing, Utilities (ISIC C-E)". The non-tradable sector comprises "Construction (ISIC F)", "Wholesale, retail trade, restaurants and hotels (ISIC G-H)", "Transport, storage and communication (ISIC I)" and "Other Activities (ISIC J-P)".

Source: Authors calculations, based on UN data (2010).

where the vector $Y_{t}=\left(\begin{array}{c}G D P_{t} \\ R E R_{t}\end{array}\right)$. Impulse response functions are computed by inverting this autoregressive model to the moving average representation.

Identification is achieved by the assumption that output in period $t$ depends on investment in period $t-1$, that is financed by bank credit. The amount of lending, in turn, depends on the real exchange rate. It is therefore assumed that the real exchange rate does not have a contemporaneous effect on GDP, but GDP can effect the real exchange rate in the same period. Given this recursive system the standard Cholesky decomposition can be applied.

The impulse response functions from this VAR are displayed in Figure 8. The graph shows the reaction of Mexico, for which a much longer time series exists, as well as the average response from the countries that have entered the previous common features analysis. ${ }^{19}$ We find that in both cases the reaction to a shock in the real exchange rate is clearly negative. About one to four quarters after

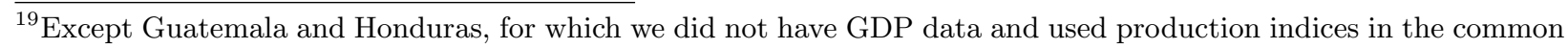
feature part.
} 
Figure 8: The role of the real exchange rate

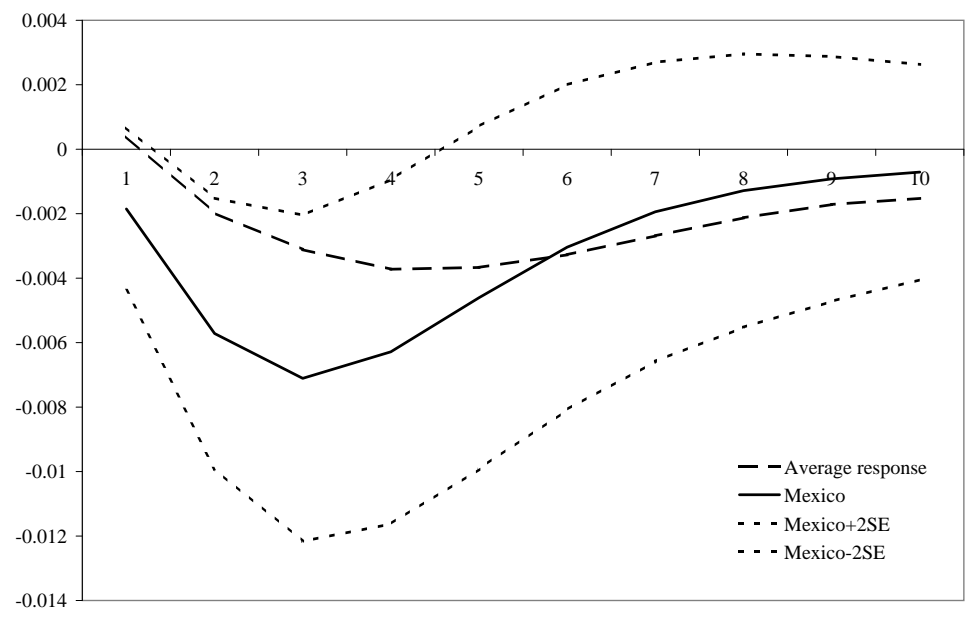

Note: The bivariate VAR includes GDP and the real exchange rate. The reaction of the GDP to a shock in the real exchange rate is displayed for Mexico (solid line). Moreover, the average response from the countries that have entered the previous common features analysis is reported (dashed line).

Source: Authors calculations, based on IADB (2010), Latin American and Caribbean Macro Watch.

an appreciation of the exchange rate, GDP will go up, and vice versa, a depreciation will trigger a decrease in GDP. This pattern is clearly at odd with conventional assumptions of the stabilizing role of the exchange rate in the Mundell model, but it can be rationalized in the alternative model that includes credit market imperfections typically present in middle income countries.

\section{Related Literature}

Over the last ten years, several researchers as well as policy makers have given a recommendation for official dollarization in Central America. ${ }^{20}$ Berg et al. (2002); Temprano-Arroyo (2003); and Salvatore (2001) discuss the issue of dollarization in Latin America and conclude that the Central American countries might be good candidates for a fixed exchange rate with the USA. Alesina et al. (2002), who test in a large set of countries whether they should belong to a dollar-, a euro-, or a yen-area, assign the Central American countries clearly to the dollar-area. ${ }^{21}$

\footnotetext{
${ }^{20}$ However, there are also some voices demanding the opposite. Fernández-Arias, Yeyati, and Morón (2006) for example, recommend de-dollarization for the Central American countries. Edwards and Magendzo (2003) find that dollarized economies grow slower than non-dollarized ones and suspect that this may be caused by difficulties in accommodating external shocks. Also Schmitt-Grohe and Uribe (2001) are sceptical of a policy of dollarization. Focusing on Mexico and using a calibrated general equilibrium model, they conclude that dollarization is the least preferable option among different monetary policy regimes, from a welfare point of view.

${ }^{21} \mathrm{~A}$ general discussion of alternative long-run strategies for monetary policy for Latin America, including currency boards and dollarization, is proposed by Mishkin and Savastano (2001), whereas Levy Yeyati and Sturzenegger (2002) provide a broad analysis of the issue of dollarization, both from the empirical and theoretical side.
} 
A recent study about the costs of macroeconomic coordination with the US for Central America was conducted in Fiess (2007). Using different filters to identify the cyclical component of GDP, he analyzes business cycle synchronization of Central America and the USA - measured by the contemporaneous correlations between the cycles - and calculates the degree of trade integration in DR-CAFTA with annual GDP data from 1965 - 2005 and monthly data on economic activity from 1995 - 2005. He finds that Costa Rica has the highest business cycle synchronization with the USA of the Central American countries, and that all of them have become more sensitive to developments of the American economy in recent years. ${ }^{22}$

The common cycle approach of Vahid and Engle (1993), that we propose as an alternative measure of comovement, has also been applied to (annual) output data in Central America in Roache (2008), although not in the context of dollarization. The author analyzes annual real GDP from 1950 to 2006 in a multivariate framework including both Central American countries and the United States. For the purpose of addressing the policy issue of dollarization, the bivariate framework, and the extension of Cubadda (2007), allows us to clearly attribute the common cycle (or the lack of it) to specific individual countries, such as Costa Rica and the US. The multivariate framework is, however, useful for addressing the issue of a potential monetary union among several countries. This has been done for instance by Cheung and Yuen (2005) in the context of a policy debate of a potential currency union in Northeast Asia. Using the approach of Vahid and Engle (1993), the authors find evidence that the three Asian economies have synchronous output movements at both long-run and short-term horizons, and thus, provide arguments in favor of a currency union.

The second part of our paper challenges the view that the OCA-Model of Mundell is the right framework to think about the issue of macroeconomic policy coordination in middle income countries. This line of argument is related to an earlier paper of Calvo (2001), who also argues - within a broader discussion of pros and cons - that the optimal currency area theory omits some important factors of emerging economies, namely recent financial crisis, combined with the existence of partial dollarization, imperfect credibility, weak financial systems and contagion. Our analysis in the second part supports his argument that the consideration of these factors can make dollarization become more attractive. ${ }^{23}$

Our analysis also complements and extends the findings of Gourinchas, Valdes, and Landerretche

\footnotetext{
${ }^{22}$ Ahmed (2003) points out that external shocks only play a limited role for business cycle fluctuations. He concludes that fixed exchange rates in Latin America may not be as costly as theory predicts.

${ }^{23}$ Also, Edwards (2009) considers the degree of partial dollarization as one of the sources of macroeconomic vulnerability and financial crisis.
} 
(2001), who study lending boom episodes and show that in Latin America particularly, they make the economy considerably more vulnerable to financial crisis. A case study on the asymmetries of the tradable and non-tradable sectors in Mexico between 1995 and 1998, i.e. the time of the recovery from the Mexican crisis, was first given in Krueger and Tornell (1999). Gelos and Werner (2002) analyze a firm-level data set on Mexican manufacturing establishments and show that especially the smallest firms are financially constrained. A model that takes account of these credit market imperfections in the context of exchange rate regime choice has been developed by Lahiri, Singh, and Végh (2007). ${ }^{24}$

In our paper, we focus on stabilization policy. This focus seems appropriate in light of the increasing evidence on the welfare cost of macroeconomic volatility in developing countries (see for instance Loayza, Rancière, Servén, and Ventura (2007)). But certainly, there are also several other pros and cons. An overview of the broader debate is given for example in Salvatore, Dean, and Willet (2003), especially in the chapters by Feige, Faulend, Šonje, and Šošić (2003); Berg and Borensztein (2003); Corbo (2003); Edwards (2003); Eichengreen (2003); Schuler (2003); and Cohen (2003). Among the pro-arguments is that a reduction of volatility in real exchange rates helps both foreign trade and foreign investment to increase. ${ }^{25}$ On the other side, the loss of monetary policy - that we discussed in the context of stabilization policy - also implies that seigniorage and the scope for acting as lender-of-last-resort are no longer possible. The second contra-argument is that in the presence of nominal rigidities, it is hard to carry out a real depreciation, i.e. in the absence of devaluation possibilities, external shocks result in greater costs than in non-dollarized countries.

Berg and Borensztein (2003) argue that the more unofficially dollarized the economy already is, the smaller are the costs of official dollarization. Eichengreen (2003) points out that the benefits depend on whether dollarization helps to speed the pace of financial, labor, and fiscal reforms. Moreover, also the number of countries that participate in the dollar area is crucial (Mundell, 2003), i.e. dollarization would be much more favorable for every single Central American country if all countries in the region decided to adopt the dollar as legal tender. A discussion of key aspects of the implementation of official dollarization is given in Jácome and Åke Lönnberg (2010).

\footnotetext{
${ }^{24}$ For a theoretical model of a small open economy and the costs of dollarization see Schmitt-Grohe and Uribe (2001).

${ }^{25}$ Freund and Spatafora (2008) show that reductions in transaction costs (e.g. by reducing the exchange rate volatility) increase remittance flows. Thus, one hypothesis to test would be that dollarization leads to an increase in remittances and thus to a stabilization of the domestic economy.
} 


\section{Conclusions}

In our paper, we have focused on two model frameworks - Mundell (1961) and Schneider and Tornell (2004) -, that can be used to address the issue of dollarization, and their opposing views about the role of the real exchange rate. The two models guide our empirical analysis of eight Central American economies.

The first contribution of our paper is a methodological point on the assessment of optimal currency areas in the Mundell framework. We emphasize that in addition to the correlation of shocks the reaction of each country to a shock is of high relevance for a common monetary policy. Even if the growth rates of the GDP are highly correlated, the reaction to a shock - that can be interpreted as the business cycle - may differ significantly across countries. We apply the test for common serial correlation to a data set from Central America, where the topic of dollarization is an important part of the discussion on stabilization policy. We can not confirm the existence of a common business cycle between the GDP growth rates of Central America and the USA. Thus, in the optimum currency area framework of Mundell (1961) dollarization would be associated with welfare losses in terms of business cycle stabilization.

Our second point is that this framework may not be adequate for the emerging middle income countries in Central America as it does not take account of the existence of credit market imperfections. Analyzing the dollarization question in the boom-bust cycle framework of Schneider and Tornell (2004), where enforceability problems and bailout expectations play a major role, leads to a new argument in favor of official dollarization: in order to protect the economies from pronounced cyclical fluctuations (in either direction), that arise from a mismatch between foreign currency denominated debt and domestic currency revenues, dollarization might be the appropriate strategy.

Which one of the two models is appropriate for a particular country depends critically on the role of the real exchange rate. The impulse response functions, generated from a vector-autoregressive (VAR) model, indicate that an unexpected change in real exchange rate leads to a pro-cyclical response of output, i.e. an appreciation leads to an increase and a depreciation to a decrease in gross domestic product. This unconventional relationship - that is typical for many middle income countries - suggests that a model with contract enforceability problems and bailout expectations, rather than the typical OCA model, provides an appropriate conceptual framework for the countries studied in this paper. 


\section{References}

Ahmed, Shaghil (2003). "Sources of economic fluctuations in Latin America and implications for choice of exchange rate regimes." Journal of Development Economics, 72(1):181 - 202.

Alesina, Alberto, Barro, Robert J., and Tenreyro, Silvana (2002). "Optimal Currency Areas." In "NBER Macroeconomics Annual 2002, Volume 17," The University of Chicago Press.

Bayoumi, Tamim and Eichengreen, Barry (1993). "Shocking Aspects of European Monetary Unification." In Torres, Francisco and Giavazzi, Francesco, eds., "Adjustment and Growth in the European Monetary Union," chapter 7. Cambridge University Press, pp. $193-241$.

Berg, Andrew, Borensztein, Eduardo, and Mauro, Paolo (2002). "An evaluation of monetary regime options for Latin America." The North American Journal of Economics and Finance, $13(3): 213-235$.

Berg, Andrew and Borensztein, Eduardo R. (2003). "The Pros and Cons of Full Dollarization." In Salvatore, Dominick, Dean, James W., and Willet, Thomas D., eds., "The Dollarization Debate," chapter 3. Oxford University Press, pp. $72-102$.

Berger, Helge, Jensen, Henrik, and Schjelderup, Guttorm (2001). "To peg or not to peg?: A simple model of exchange rate regime choice in small economies." Economics Letters, 73(2):161 $-167$.

Bordo, Michael, Eichengreen, Barry, Klingebiel, Daniela, and Martinez-Peria, Maria Soledad (2001). "Is the crisis problem growing more severe?" Economic Policy, 16(32):51 - 82.

Calvo, Guillermo A. (2001). "Capital Markets and the Exchange Rate, with Special Reference to the Dollarization Debate in Latin America." Journal of Money, Credit and Banking, 33(2):312 334.

Caprio, G. and Klingebiel, D. (2003). "Episodes of Systemic and Borderline Financial Crisis." Technical report, The World Bank, Research Datasets.

Cheung, Yin-Wong and Lai, Kon S (1993). "Finite-Sample Sizes of Johansen's Likelihood Ration Tests for Cointegration." Oxford Bulletin of Economics and Statistics, 55(3):313 - 328.

Cheung, Yin-Wong and Lai, Kon S. (1995). "Lag Order and Critical Values of the Augmented Dickey-Fuller Test." Journal of Business \& Economic Statistics, 13(3):277 - 280.

Cheung, Yin-Wong and Yuen, Jude (2005). "An Output Perspective on a Northeast Asia Currency Union." In Grauwe, Paul De and Mélitz, Jacques, eds., "Prospects for Monetary Unions after 
the Euro," MIT Press, Cambridge and London, pp. 289 - 317.

Cohen, Benjamin J. (2003). "Monetary Union: The Political Dimension.” In Salvatore, Dominick, Dean, James W., and Willet, Thomas D., eds., "The Dollarization Debate," chapter 13. Oxford University Press, pp. $221-237$.

Corbo, Vittorio (2003). "Is It Time for a Common Currency for the Americas?" In Salvatore, Dominick, Dean, James W., and Willet, Thomas D., eds., "The Dollarization Debate," chapter 4. Oxford University Press, pp. $102-110$.

Cubadda, Gianluca (1999). "Common Cycles in Seasonal Non-stationary Time Series." Journal of Applied Econometrics, 14(3):273 - 291.

Cubadda, Gianluca (2007). "A unifying framework for analysing common cyclical features in cointegrated time series." Computational Statistics $\mathcal{G}$ Data Analysis, 52(2):896 - 906.

De Grauwe, Paul (1994). The economics of monetary integration. Oxford University Press, New York.

Edwards, Sebastian (2003). "Dollarization: Myths and Realities." In Salvatore, Dominick, Dean, James W., and Willet, Thomas D., eds., "The Dollarization Debate," chapter 5. Oxford University Press, pp. $111-128$.

Edwards, Sebastian (2009). "Sequencing of reforms, financial globalization, and macroeconomic vulnerability." Journal of the Japanese and International Economies, 23(2):131 - 148.

Edwards, Sebastian and Magendzo, I. Igal (2003). "Dollarization and Economic Performance: What Do We Really Know?." International Journal of Finance and Economics, 8(4):351 - 363.

Eichengreen, Barry (2003). "What Problems Can Dollarization Solve?" In Salvatore, Dominick, Dean, James W., and Willet, Thomas D., eds., "The Dollarization Debate," chapter 6. Oxford University Press, pp. $129-139$.

Engle, Robert F. and Kozicki, Sharon (1993). "Testing for Common Features." Journal of Business \& Economic Statistics, 11(4):369 - 380.

Feige, Edgar L., Faulend, Michael, Šonje, Velimir, and Šošić, Vedran (2003). "Unofficial Dollarization in Latin America: Currency Substitution, Network Externalities, and Irreversibility." In Salvatore, Dominick, Dean, James W., and Willet, Thomas D., eds., "The Dollarization Debate," chapter 2. Oxford University Press, pp. 46 - 71.

Fernández-Arias, Eduardo, Yeyati, Eduardo Levy, and Morón, Eduardo (2006). "Financial 
Dollarization and Dedollarization [with Comments]." Economía, 6(2):37 - 100.

Fiess, Norbert (2007). "Business Cycle Synchronization and Regional Integration: A Case Study for Central America." World Bank Economic Review, 21(1):49 - 72.

Freund, Caroline and Spatafora, Nikola (2008). "Remittances, transaction costs, and informality." Journal of Development Economics, 86(2):356 - 366.

Gelos, R. Gaston and Werner, Alejandro M. (2002). "Financial Liberalization, Credit Constraints, and Collateral: Investment in the Mexican Manufacturing Sector." Journal of Development Economics, 67(1):1 - 27.

Goldfajn, Ilan, Olivares, Gino, Frankel, Jeffrey, and Milesi-Ferretti, Gian Maria (2001). "Full Dollarization: The Case of Panama [with Comments]." Economía, 1(2):101 - 155.

Gourieroux, Christian and Peaucelle, Irina (1989). "Detecting a long run relationship (with an application to the p.p.p. hypothesis)." CEPREMAP Working Papers (Couverture Orange) 8902, CEPREMAP.

Gourinchas, Pierre-Olivier, Valdes, Rodrigo, and Landerretche, Oscar (2001). "Lending Booms: Latin America and the World." Economia, 1(2):47 - 97.

Jácome, Luis I. (2008). "Central Bank Involvement in Banking Crises in Latin America." IMF Working Paper 08/135, International Monetary Fund.

Jácome, Luis I. and Åke Lönnberg (2010). "Implementing Official Dollarization." IMF Working Paper WP/10/106, International Monetary Fund.

Johansen, Søren (1988). "Statistical analysis of cointegration vectors." Journal of Economic Dynamics and Control, 12(2-3):231 - 254 .

Johansen, Søren (1991). "Estimation and Hypothesis Testing of Cointegration Vectors in Gaussian Vector Autoregressive Models." Econometrica, 59(6):1551 - 1580.

Kaminsky, Graciela L and Reinhart, Carmen M (1998). "Financial Crises in Asia and Latin America: Then and Now." American Economic Review, 88(2):444 - 448.

Kaminsky, Graciela L. and Reinhart, Carmen M. (1999). "The Twin Crises: The Causes of Banking and Balance-of-Payments Problems." American Economic Review, 89(3):473 - 500.

Kenen, P.B. (1969). "The theory of optimum currency areas: an eclectic view." In Mundell, R.A. and Swoboda, A.K., eds., "Monetary Problems of the International Economy," University of Chicago Press, pp. $41-60$. 
Krueger, Anne and Tornell, Aaron (1999). "The Role of Bank Restructuring in Recovering from Crises: Mexico 1995-98." NBER Working Papers 7042, National Bureau of Economic Research, Inc.

Laeven, Luc and Valencia, Fabian (2008). "Systemic Banking Crises: A New Database." IMF Working Paper 08/224, International Monetary Fund.

Lahiri, Amartya, Singh, Rajesh, and Végh, Carlos (2007). "Segmented asset markets and optimal exchange rate regimes." Journal of International Economics, 72(1):1 - 21.

Levy Yeyati, Eduardo and Sturzenegger, Federico (edt.) (2002). Dollarization: Debates and Policy Alternatives. MIT Press, Cambridge and London.

Loayza, Norman V., Rancière, Romain, Servén, Luis, and Ventura, Jaume (2007). "Macroeconomic Volatility and Welfare in Developing Countries: An Introduction." World Bank Economic Review, 21(3):343 - 357.

McKinnon, Ronald I. (1963). "Optimum Currency Areas." The American Economic Review, $53(4): 717-725$.

Mishkin, Frederic S. and Savastano, Miguel A. (2001). "Monetary policy strategies for Latin America." Journal of Development Economics, 66(2):415 - 444.

Mundell, Robert (2003). "Currency Areas, Exchange Rate Systems, and International Monetary Reform." In Salvatore, Dominick, Dean, James W., and Willet, Thomas D., eds., "The Dollarization Debate," chapter 1. Oxford University Press, pp. 17 - 46.

Mundell, Robert A. (1961). "A Theory of Optimum Currency Areas." The American Economic Review, 51(4):657 - 665 .

Osterwald-Lenum, Michael (1992). "A Note with Quantiles of the Asymptotic Distribution of the Maximum Likelihood Cointegration Rank Test Statistics." Oxford Bulletin of Economics and Statistics, 54(3):461 - 472 .

Roache, Shaun K. (2008). "Central America's Regional Trends and U.S. Cycles." IMF Working Papers 08/50, International Monetary Fund.

Salvatore, Dominick (2001). "Which countries in the Americas should dollarize?" Journal of Policy Modeling, 23(3):347 - 355.

Salvatore, Dominick, Dean, James W., and Willet, Thomas D. (2003). The Dollarization Debate. Oxford University Press, New York. 
Schmitt-Grohe, Stephanie and Uribe, Martin (2001). "Stabilization Policy and the Costs of Dollarization." Journal of Money, Credit and Banking, 33(2):482 - 509.

Schneider, Martin and Tornell, Aaron (2004). "Balance Sheet Effects, Bailout Guarantees and Financial Crises." Review of Economic Studies, 71(3):883 - 913.

Schuler, Kurt (2003). "What Use Is Monetary Sovereignty?" In Salvatore, Dominick, Dean, James W., and Willet, Thomas D., eds., "The Dollarization Debate," chapter 7. Oxford University Press, pp. $140-153$.

Temprano-Arroyo, Helidoro (2003). "Prospects for Regional Monetary Integration in Latin America: A View from the EU." Comparative Economic Studies, 45(3):384 - 420.

Tornell, Aaron and Westermann, Frank (2002). "Boom-Bust Cycles in Middle Income Countries: Facts and Explanation." IMF Staff Papers, 49(Special Issue):111 - 155.

Tornell, Aaron and Westermann, Frank (2005). Boom-Bust Cycles and Financial Liberalization. MIT Press Books. The MIT Press.

Urga, Giovanni (2007). "Common Features in Economics and Finance: An Overview of Recent Developments." Journal of Business \& Economic Statistics, 25:2 - 11.

Vahid, F and Engle, Robert F (1993). "Common Trends and Common Cycles." Journal of Applied Econometrics, 8(4):341 - 360.

Vahid, Farshid and Engle, Robert F. (1997). "Codependent cycles." Journal of Econometrics, 80(2):199 - 221. 


\section{Appendix}

Table A.1: Results of ADF-test for GDP data

\begin{tabular}{|c|c|c|c|c|c|c|}
\hline \multicolumn{7}{|c|}{ 1997:1 - 2008:1 } \\
\hline & \multicolumn{3}{|c|}{ Level } & \multicolumn{3}{|c|}{ 1st differences } \\
\hline & lags & statistic & crit. value & lags & statistic & crit. value \\
\hline Costa Rica $^{\text {a) }}$ & 4 & -2.75 & -3.46 & 0 & $-10.51 * *$ & -2.95 \\
\hline Dominican Rep. ${ }^{\text {a) }}$ & 0 & -1.10 & -3.54 & 0 & $-6.167 * *$ & -2.95 \\
\hline El Salvador ${ }^{\text {b) }}$ & 4 & -0.51 & -2.89 & 1 & $-4.958 * *$ & -2.93 \\
\hline Guatemala & 0 & -0.75 & -2.95 & 0 & $-7.712 * *$ & -2.95 \\
\hline Honduras & 4 & -1.47 & -2.89 & 3 & $-5.773 * *$ & -2.90 \\
\hline Mexico & 1 & -1.09 & -2.93 & 0 & $-4.271 * *$ & -2.95 \\
\hline Nicaragua & 2 & -0.90 & -2.92 & 1 & $-7.590 * *$ & -2.93 \\
\hline Panama ${ }^{\text {a) }}$ & 1 & 1.43 & -3.52 & 1 & $-3.051 * *$ & -2.93 \\
\hline USA & 0 & -2.66 & -2.95 & 1 & $-2.964 * *$ & -2.93 \\
\hline
\end{tabular}

Note: ADF-test statistics are reported for the sample 1997:1 - 2008:1 (quarterly data). The ADF-test was conducted in levels and in first differences. The lag length was selected by the SIC criterion. Critical values of Cheung and Lai (1995) were applied. ** indicate rejection of the existence of both, stochastic and deterministic, trends with a significance of 5\%. a) A trend has been included in the estimation equation. b) For El Salvador the ADF-test in first differences has been conducted with only one lag (selected manually; SIC would require 3 lags).

Source: Authors calculations, based on IADB (2010), Banco de Guatemala, and IMF (2010).

Table A.2: Results of Johansen cointegration test

\begin{tabular}{|c|c|c|c|c|c|c|c|c|c|c|}
\hline \multicolumn{11}{|c|}{ 1997:1 - 2008:1 } \\
\hline \multicolumn{11}{|c|}{ Johansen Test (Maximum Eigenvalue Statistic) } \\
\hline & & & Costa Rica & Dom. Rep. & $\begin{array}{c}\text { El } \\
\text { Salvador }\end{array}$ & Guatemala & Honduras a) & Mexico & Nicaragua & Panama \\
\hline \multirow[t]{5}{*}{ USA } & $\mathrm{r}=0$ & Statistic & 11.15 & $22.10^{* * *}$ & $22.54^{* * *}$ & $24.06^{* * *}$ & $26.76 * *$ & 15.67 & $31.00^{* * *}$ & 8.99 \\
\hline & & Crit.Val. & 17.20 & 16.40 & 16.40 & 16.40 & 26.12 & 18.08 & 16.40 & 19.15 \\
\hline & & Vector & -2.13 & -0.09 & -1.29 & -0.94 & -2.44 & -0.75 & -0.42 & 0.45 \\
\hline & $\mathrm{r}=1$ & Statistic & 4.54 & 2.87 & 2.96 & 5.70 & 9.91 & 3.99 & $19.16 * * *$ & 3.54 \\
\hline & & Crit.Val. & 10.14 & 9.67 & 9.67 & 9.67 & 15.40 & 10.66 & 9.67 & 11.29 \\
\hline
\end{tabular}

Note: Results of testing for cointegration between the GDPs of the Central American countries and the USA are shown for the sample 1997:1 - 2008:1. The Table contains the Maximum Eigenvalue statistics for $\mathrm{r}=0$ and $\mathrm{r}=1$. The critical values of Osterwald-Lenum (1992) were scaled with the scaling factor of Cheung and Lai (1993) to adjust for finite samples. $* * *, * *$ indicates the rejection of the null hypothesis with a significance of $1 \%, 5 \%$. a) To test for cointegration with Honduras, industrial production instead of GDP has been used for the USA.

Source: Authors calculations, based on IADB (2010), Banco de Guatemala, and IMF (2010). 
Table A.3: Results of serial correlation common feature and codependence tests with 4 lags

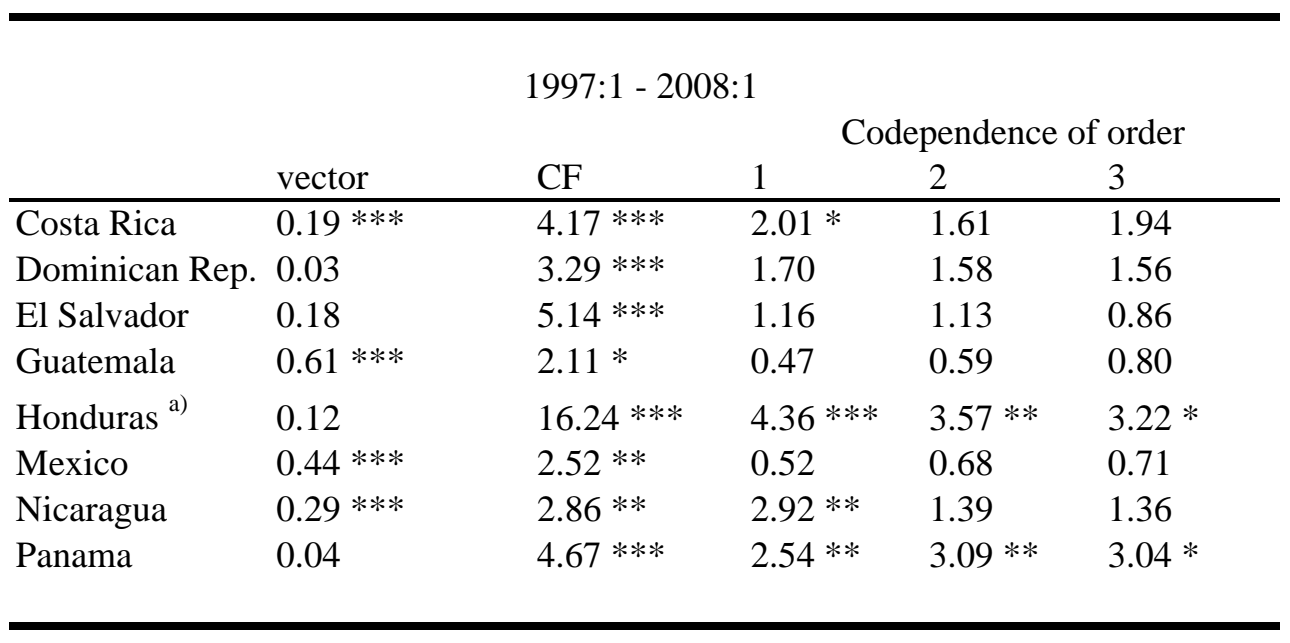

Note: Results of the TSLS estimation of serial correlation common features and codependence between the GDP growth rates of Central American countries and the USA are reported for the sample 1997:1 - 2008:1. Independently of the true lag structure, all equations have been estimated with 4 lags. Error-correction terms have been included for Dominican Republic, El Salvador, Guatemala, and Honduras. The column $C F$ gives the F-statistic for the serial correlation common feature test, and the columns titled codependence of order 1, 2, 3 report the F-statistic for the codependence test. The column vector contains the coefficient $\beta$ of the common feature vector. ${ }^{* * *}$, ** indicates the rejection of the null hypothesis with a significance of $1 \%, 5 \%$. Please note, that in some cases the non-rejection of the null hypothesis is trivial (e.g. as in the case of the codependence tests for Nicaragua, where both countries, Nicaragua and the US, have a lag structure of 1). a) To test for a common feature with Honduras, industrial production instead of GDP has been used for the USA.

Source: Authors calculations, based on IADB (2010), Banco de Guatemala, and IMF (2010). 
Table A.4: Systemic banking and currency crisis in Central America

\begin{tabular}{|c|c|c|c|c|}
\hline & \multicolumn{2}{|c|}{ Systemic Banking Crises } & \multicolumn{2}{|c|}{ Currency Crisis } \\
\hline & Year & Source & Year & Source \\
\hline Belize & -- & -- & -- & -- \\
\hline \multirow[t]{2}{*}{ Costa Rica } & 1987 & $\begin{array}{l}\text { B01, CK03, } \\
\text { LV08 }\end{array}$ & 1981 & LV08 \\
\hline & 1994-1997 & $\begin{array}{l}\text { B01, CK03, } \\
\text { J08, LV08 }\end{array}$ & 1991 & LV08 \\
\hline \multirow[t]{3}{*}{ Dom. Rep. } & 1996 & J08 & 1985 & LV08 \\
\hline & 2003 & J08, LV08 & 1990 & LV08 \\
\hline & & & 2003 & LV08 \\
\hline \multirow[t]{2}{*}{ El Salvador } & 1989 & CK03, LV08 & 1986 & LV08 \\
\hline & 1998 & J08 & & \\
\hline \multirow[t]{3}{*}{ Guatemala } & 1991 & CK03 & 1986 & LV08 \\
\hline & 2001 & J08 & & \\
\hline & 2006 & J08 & & \\
\hline \multirow[t]{3}{*}{ Honduras } & 1999 & J08 & 1990 & LV08 \\
\hline & 2001 & J08 & & \\
\hline & 2002 & J08 & & \\
\hline \multirow[t]{4}{*}{ Mexico } & 1981-1982 & B01, LV08 & 1977 & LV08 \\
\hline & 1982-1991 & KR99, CK03 & 1982 & LV08 \\
\hline & 1992 & KR99 & 1995 & LV08 \\
\hline & 1994-1997 & $\begin{array}{l}\text { B01, CK03, } \\
\text { J08, LV08 }\end{array}$ & & \\
\hline \multirow[t]{3}{*}{ Nicaragua } & 1987-1996 & CK03 & 1979 & LV08 \\
\hline & 1990 & LV08 & 1985 & LV08 \\
\hline & $2000-2002$ & J08, LV08 & 1990 & LV08 \\
\hline Panama & 1988-1989 & CK03, LV08 & -- & -- \\
\hline
\end{tabular}

Note and Source: The Table reports the systemic banking crisis and currency crisis of Central America since the 1980s that have been reported by various authors. B01 refers to Bordo, Eichengreen, Klingebiel, and Martinez-Peria (2001), CK03 to Caprio and Klingebiel (2003), J08 to Jácome (2008), KR99 to Kaminsky and Reinhart (1999), and LV08 to Laeven and Valencia (2008). 